ley Laboratory) reported that three huge landslides fell into Lake Washington, just east of Seattle, about 1,100 years ago, and that two others occurred there about 1,700 years ago. He suggested that the slides were triggered by great earthquakes on the Cascadia subduction zone.

The suggestion that great Cascadia subduction earthquakes occur has evolved in the past decade from hypothetical conjecture to a widely discussed model that seems to provide the best explanation for many observations. Yet, with the subduction zone quiet since Europeans arrived in northwestern America about 200 years ago, few of the region's 10 million people have become prepared for the minutes of strong ground shaking and the devastating tsunami that a great Cascadia earthquake would produce. Although basic scientific questions remain about the earthquake potential of the Cascadia subduction zone, many researchers feel that the evidence is sufficient to warrant updating building codes (particularly in Oregon) and tsunami evacuation plans to reflect the potential for great subduction earthquakes.

Thomas H. Heaton is at the US Geological Survey, 525 South Wilson Avenue, Pasadena, California 91106, USA.

\section{Earthquake magnitude scales}

Charles Richter's original magnitude scale (usually called the local magnitude $M_{L}$ ), developed in the 1930s, was designed to measure the size of waves recorded in southern California for local earthquakes. To genera'ize the restrictive range of seismograms and earthquakes that could be quantified with the local magnitude scale, many other magnitude scales have been developed in the past $\mathbf{5 0}$ years. Surface-wave magnitude $\left(\boldsymbol{M}_{\mathrm{s}}\right)$ measures the size of longperiod surface waves recorded at large distances from earthquakes and it is one of the most popular magnitude scales in use today. It became clear in the 1970 s that existing magnitude scales did not adequately represent the total energy of very large earthquakes. $\boldsymbol{M}_{w}$ is an energy magnitude scale obtained from estimates of the total kinetic energy radiated by an earthquake (H. Kanamori J. geophys. Res. 82, 2981 - 2987; 1977). It is defined to give values comparable to Richter's original magnitude scale for earthquakes as large as magnitude 6 . For each unit increase in $M_{w}$, the total kinetic energy increases by a factor of 31.6. Therefore an earthquake of $M_{w}=9.0$ radiates about 1,000 times as much kinetic energy as the recent 17 October $1989 M_{w}=7.0$ Loma Prieta earthquake in California. Unfortunately, the many different existing magnitude scales are generally all included together in the maddeningly vague term 'Richter Scale', which is popular with the press, but meaningless to a seismologist.

T.H.H.

\title{
Colour consciousness in archaeology
}

Adela Catherine Breton (1849-1923), the painter of the picture reproduced below, has a special place in the history of Maya archaeology. In 13 visits to Mexico and Central America around the turn of the century, she photographed and painted the major prehispanic ruins and, at her death, bequeathed her collections to Bristol City Museum. The Museum has, for the first time, put the best of this material on display*.

What excites professional mayanists is the series of watercolour copies Breton made of wall paintings and architectural details, many of which are now damaged beyond repair. Her diaries describe how sacred or precious, pertaining to worship and to the divine rights of kings.

In her lifetime Adela Breton was highly regarded by the founding fathers of Maya research, but her work was largely neglected in the 1960s and 1970s, when archaeology was attempting to be a science and its practitioners were barely speaking to the art historians. Today there is a happier relationship between dirt archaeologists, epigraphers and art historians, and I predict that many specialists will make their way to Bristol.

At the time when the Breton exhibition was opening, a disquieting report appeared in Vol. 11 of The Pre-Columbian Art

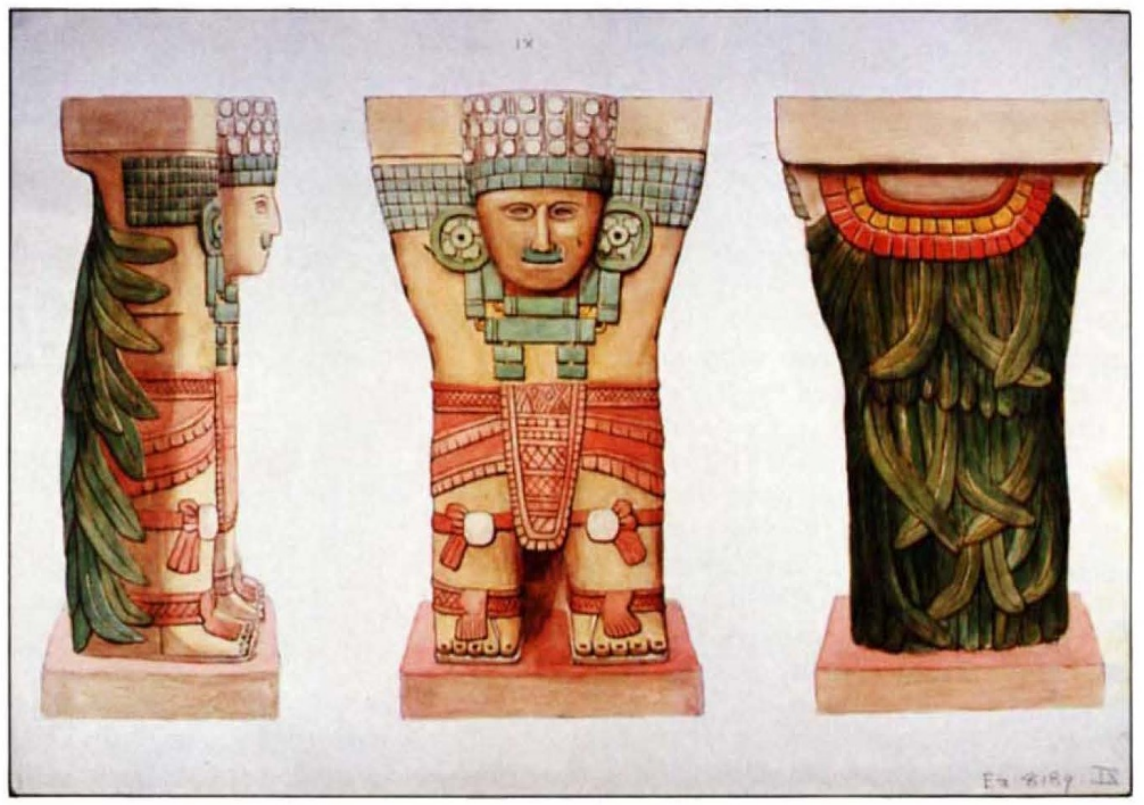

she searched out traces of pigment in cracks and crannies in order to produce original-colour renderings of sculptured monuments. The example illustrated here (a caryatid from the Upper Temple of the Jaguars at Chichén Itzá) may disconcert tourists used to the beauty of plain stone, but this colour is what the Maya artist meant us to see. Without it, one would not realize that the cape was made of green quetzal feathers and the necklace of jade.

To a Maya observer, details of costume and insignia gave precise information about a personage's nature (human or divine) and about his rank and status in the world. A decorated Maya facade was designed to be 'read' for its message as well as appreciated for its beauty, and in this system of visual communication colour-coding played a vital part. Red, for instance, was used for human figures; blue was reserved for gods and for things

*The Art of Ruins: Miss Adela Breton and the Temples of Mexico is at the City of Bristol Museum and Art Gallery, Queen's Road, Bristol, until 10 March.
Research Institute Newsletter on the damage done to Maya monuments by acid rain, algae, windblown dust and the ravages of mass tourism. This survey draws on a three-year investigation by Merle Robertson on behalf of the National Geographic Society. To quote from the summary: "there is not going to be any visible sculpture or painted buildings or any kind of buildings for that matter a 100 years from now. The paint will be gone long before that, in fact, it is almost all gone NOW". Already the world-famous Bonampak murals, after a generation of mistreatment, can be better appreciated in museum replicas than in the original temple, and Palenque was documented just in time. Meanwhile, Adela Breton's fine watercolours become increasingly precious records of Maya culture.

Warwick Bray

Warwick Bray is at the Institute of Archaeology, University College London, 31-34 Gordon Square, London WC1 OPY, UK, and at the Institute of Latin American Studies, London University. 